\title{
EATING BEHAVIORS OF PRESCHOOL-AGED CHILDREN - GENDER-LINKED DIFFERENCES
}

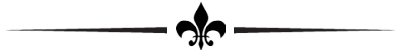 \\ KÁSLER, TIMEA

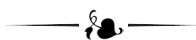 \\ Corvinus University of Budapest, Institute of Marketing and Media \\ H-1093 Budapest, Fővám tér 8. \\ email: tina.toth@yahoo.com
}

\begin{abstract}
7 A growing popularity in the consumption of foods with low nutritional value is increasing amongst the preschool age groups worldwide, which is partially responsible for the increase of childhood obesity rates globally. Thus, it is vital to examine the eating behavior of preschool aged children, as these are known to effect the daily energy intake. On the contrary, gender differences could possibly also influence the food intake and therefore health-related outcomes in children. In order to investigate the relationship between the children's eating behavior and their gender, a survey was conducted amongst the parents of children aged between 3-7 in Hungary, which included Wardle et al.'s (2001a) 35-item instrument, the Children's Eating Behavior Questionnaire, together with questions concerning possible food allergies and demographics. The sample of size N=365 was then analyzed using SPSS via the INDSCAL method. The initial creators of the Child Eating Behavior Questionnaire found only one gender difference, namely that the incidence of eating fussiness was slightly higher in boys, the findings of the current study were able to verify this result together with other dissimilarities. The findings indicate that other eating behaviors can be linked to gender, including that girls' desire to drink, which is generally higher than that of boys and that boys tend to eat slower than girls. Boys also lean towards emotional undereating, while girls have a tendency towards emotional overeating. The information above can be of great use to marketers in the food and beverage industry as well as the healthcare industry.
\end{abstract}

KEYWORDS: eating behavior, preschool-aged children, gender, Children's Eating Behavior Questionnaire, consumer behavior

JEL-KóDOK (JEL CODES): I12, M31

DOI: https://doi.org/10.20494/TM/6/2/2

\section{INTRODUCTION}

As foods with low nutritional value are demanded at a higher rate by small children, childhood obesity rates increase. There are also concerns about what other long-term health consequences this new trend may have. Whilst children themselves cannot be held accountable for this unfortunate development, not all factors influencing eating behavior are modifiable, such as the environmental factors and food-related experiences (DECOSTA et al., 2017). Studying the eating behaviors, however can lead to a better understanding of various types of eating disorders as well as food preferences and can therefore increase the overall health of children at such a young age. Certain differences in behavior can be traced back to gender differences, even at this age; however, what relation gender has with eating behaviors in this age group remains to be studied in detail. Connecting eating behavior with gender studies is a rather understudied subject, especially in the preschool age range, even though studies have found that children's eating habits can be subjected to an agerelated decline in dietary quality (LYTLE et al., 2000). It is vital to understand how children's 
preferences and behaviors are shaped, as different behaviors, such as eating pace and eating fussiness can have drastic consequences such as poor dietary variety and energy intake during early childhood. This, in turn, can lead to poor nutrition and thus to possibly adverse health-related outcomes (TAYLOR et al., 2015).

\section{LITERATURE REVIEW}

Firstly, it is vital to define gender as well as pre-school children's consumer behavior. VALKENBURG and CANTOR (2001) have attempted to do so from infancy to 12 years of age. Although there is no single definition of consumer behavior in the literature, those that have been employed, seem to entail at least four characteristics. According to Valkenburg and Cantor, young consumers are able to feel desires and preferences, they are also able to search to fulfil them, they are able to choose and make a purchase, and finally they are able to evaluate the product and its alternatives. The development of consumer behavior occurs in four phases, in each phase, one of the four characteristics of consumer behavior emerges.

Gender has a long history in marketing, and it is an important segmentation variable. Culturally, gender describes behavior seen as being applicable to the sexes in a given society at a given time (LERNER, 1986). Initial research on the gender differences in the eating behaviors of children showed eating habits in an early age are similar, regardless of the child's gender (LYTLE et al., 2000; PEREZ-RODRIGO et al., 2003; SVENSSON et al., 2011; WILSON, 2000). However, numerous other studies were able to find minor differences between the eating behaviors of the children.

In regards to fussy eating, a study done by RYDELL et al. (1995) found, that approximately one third of both boys and girls are fussy eaters. This was also underlined by HOLM-DENOMA et al. (2005), who found, that boys and girls exhibit similar levels of pickiness, however, fathers reported that boys refused food more often. COOKE and WARDLE (2005) on the other hand, found that younger boys disliked more foods than girls, whereas in the older groups, this effect was reversed. MARCHI and
COHEN (1990) found that fussy eating and fixating on weight is more common in girls than boys. However, MOROSHKO and BRENNAN (2013) found that picky eating affects girls and boys equally. In addition, another study found that boys identified as fussy eaters were more likely to throw tantrums than both fussy girls and non-picky children. Picky eaters were reported to eat a limited variety of foods, require food to be prepared in specific ways, be less likely to accept new foods, and have strong likes and dislikes in food. Furthermore, parents of fussy boys were more likely to offer a reward to encourage eating than parents of fussy girls were (MASCOLA et al., 2010). The creators of the Child Eating Behavior Questionnaire found that the only gender difference amongst children was that eating fussiness was slightly more frequent in boys than in girls (WARDLE et al., 2001a).

A study regarding emotional overeating found that girls with low mother/child relationships were prone to emotional overeating. This was not the case for girls with high mother/child relationships or for boys with either high or low mother/child relationships (ESCOBAR et al., 2014). A Canadian study of 3-year-olds suggested, that girls had a significantly greater ability than boys did to delay responding to eating impulse. The girls' impulsive responding toward a sweet reward predicted increased consumption of palatable fat and higher body mass index. The study's findings suggest that in girls, the quality of fetal growth may contribute to impulsive eating. This may promote an increased intake of fats (SILVEIRA et al., 2012). According to SALVY et al. (2007), overweight girls consumed more kcal when they ate with an overweight peer compared to when they ate with a normalweight peer.

A study by COOKE and WARDLE (2005) on food preferences in children showed that girls liked fruit and vegetables more than boys did, whereas boys liked fatty and sugary foods, meat, processed meat products and eggs more than girls did. The first part of these findings was supported by other studies, such those conducted by WARDLE et al. (2001b) and LE BIGOT MACAUX (2001). There was a significant age-by-gender interaction in the 
number of foods disliked, with younger boys disliking more foods than girls, whereas in the older groups this effect was reversed (COOKE and WARDLE, 2005).

DEL TORO and GREENBERG (1989) surveyed high school students on television behaviors, particularly those related to television commercials, in conjunction with food preferences, consumption, and buying behaviors. Girls expressed more desire than boys for TV-advertised foods and had more positive attitudes toward television commercials. YAVAS and ABDUL-GADER (1993) also confirmed that Saudi grade 5-8 girls liked food adverts significantly more than boys did. KELLER et al. (2012) also found that girls ate about 100 calories more when the meals were branded compared to unbranded. It has been concluded, that regarding boys, television viewing while eating a meal contributes to increased energy intake by delaying normal mealtime satiation and reducing satiety signals from previously consumed foods (BELLISSIMO et al., 2007). Boys' and girls' brand knowledge seemed to be alike as both genders received the same exposure to information and entertainment (MCNEAL, 1992). A study by ROMERO et al. (2009) found that girls exposed to the large serving size video consumed more cookies compared to those exposed to the small serving size video.

Eating behaviors and attitudes to eating, dieting and body image were studied in 7-yearold Swedish girls. The results indicate that one-quarter of 7-year-old girls have concerns regarding their body weight and that they make attempts to lose weight (EDLUND et al., 1996). Similar results were found in an Israeli study by SASSON et al. (1995).

An investigation of the parental feeding habits of 3-year-old children showed, that parents often report the eating habits of children differently, depending on the gender of the child (HOLM-DENOMA et al., 2005). A study on parental controlled feeding practices showed that only for boys was pressure to eat positively associated with eating in the absence of hunger (HARRIS et al., 2014). Another study found that, for boys, significant predictors of body weight were family food insecurity and conflicts during mealtime. Healthy eating was predicted by food insecurity, mealtime conflicts, and sedentary behaviors. For girls, none of the variables predicted body weight; however, food insecurity predicted less healthy eating (TREMBLAY and RINALDI, 2010). Also due to differing parental perception of offspring body size, the feeding habits of parents can differ, too. Mothers reported that their daughters ate enough food, but not that their sons did. Finally, mothers worried about their sons being underweight, but not that their daughters were underweight. Fathers also worried about their sons, but not their daughters, being underweight (HOLMDENOMA et al., 2005). Girls were rated as significantly more emotional than boys and significantly more active than girls (HAYCRAFT et al., 2011). Girls are also more likely to be responsive towards peer models compared to boys, where new foods presented with enthusiastic teacher modelling and enthusiastic peer modelling for a competing food (HENDY and RAUDENBUSH, 2000).

A study by GUELINCKX et al. (2015) described the intake of water and all other beverages in children in 13 countries on three continents. The findings showed that water and hot beverage intake was slightly higher for girls than boys, whereas total intake of milk, juices and soda was higher for boys. There were also significant differences within certain countries, i.e., boys in the UK and China had a significantly higher soda contribution to their total fluid intake than girls.

It has to be noted, that the current study was conducted in Hungary, thus the general eating behavior of the country might alter the results of the outcomes slightly. Still a study conducted by BARTA and SZÚCCS (2015) underlined, that Hungarian children are also exposed to a great amount of brand-related cartoon characters, logos and slogans through television advertisements, while their remembering rate is shockingly high. The children's favorite ads were food advertisements and games (e.g. LEGO). The most popular advertisement was however Jófogás (a special Hungarian advertisement with a plush toy), yet it was closely followed by Paula Pudding, Milka, and Coca-Cola. Though no similar study was 
yet conducted to the current one, KELLER et al. (2016) looked into the differences in the eating behaviors of grownups in Hungary, also looking into gender related differences using the Three Factor Eating Questionnaire (TFEQ). The study found that Emotional eating (EE) and cognitive control eating are typical eating styles among women and that cognitive control eating is typical for people belonging to $\mathrm{Y}$ generation, however children were not included in the study. Still, according to HOFMEISTER-TÓTH (2016) health is the most important value to Hungarians, however in terms of achievement it is only ranked 14th for the general population. Thus healthy eating and food shopping is not a significant factor for Hungarians, although a small segment was detected who are health-conscious and seek healthy nutrition characteristics (DÖRNYEI et al., 2014). Namely, young couples and emptynest households proved to have the most health-conscious eating habits. Full-nest and single-parent groups also reported a high level of awareness of healthy food intake. Young singles, delayed nest and elderly singles/ couples have the least healthy lifestyles, ignoring most aspects of healthy living (NEULINGER and SIMON, 2011). In fact, 19\% of the Hungarian children aged 8-12 and 27\% of 13-14 year-olds visit fast-food chains at least once a month (NEULINGER, 2015). Reflecting on past Hungarian studies highlights, that the eating behavior in Hungary is close from seamless, thus it is essential to examine the eating behavior of children in specific, as wrong embedded behaviors can accompany a person through their entire life.

\section{Material and Method}

The present study aims to analyze the relationship between eating behavior and gender among preschool-aged children. Past theoretical frameworks suggest that while differences do exist, they are minimal. However, past research only focused on one eating behavior at a time, such as food selection or fussy eating; whereas the purpose of this study is to evaluate what types of eating behaviors are different between genders. Based on existing work, it is hypothesized further, that gender differences in eating behavior are most profound in relation to emotional eating as well as fussy eating. Finally, the present study aims to examine how much of the gender differences in eating behavior are left unexplained regarding the preschool age group.

Numerous psychometric instruments have been developed in the past in order to assess the eating behavior in children, including the Children's Eating Behavior Inventory (ARCHER et al., 1991), the Bob and Tom's Method of Assessing Nutrition (BABBITT et al., 1995) and the Children's Eating Behavior Questionnaire (WARDLE et al., 2001a). The latter is generally regarded as one of the most comprehensive instruments in assessing children's eating behavior, therefore it was also selected for the current study. The questionnaire was developed and validated in the United Kingdom. It has been used for different research purposes, such as to examine the relationship between obesity and eating behaviors (CARNELL and WARDLE, 2007; RODGERS et al., 2013), the relationship with body mass index (POWERS et al., 2006; VIANA et al., 2008) to examine continuity in children's eating behaviors across time (ASHCROFT et al., 2007) and to examine the relations between children's maternal feeding practices (AINUKI and RIE, 2011; BLISSETT et al., 2010).

WARDLE et al.'s (2001a) Children's Eating Behavior Questionnaire has 35-items with eight scales, this survey was taken as a basis for the current study for the reasons stated above. The survey was first translated into Hungarian and then back into English, to make sure the translations were appropriate. The 35-item Children's Eating Behavior Questionnaire was therefore the first section of the survey, followed by questions concerning possible food allergies and finally demographic questions regarding the children and their parents. The survey was conducted online in 2016 with parents whose children were between 3 and 7 years old. It is important to note, that the differences in the eating behaviors of genders has not been analyzed in Hungary so far, however, it is vital to do so, as the eating preferences can 
influence the future choice of brands related to foods and beverages of the children. The sample of size $\mathrm{N}=365$ was then analyzed using SPSS via the INDSCAL method to investigate the relationship between the children's eating behaviors and their gender.

The sample consisted of 365 parents of preschool children aged 3-7 years. Regarding the socio-demographic characteristics of the children and their mothers, 190 respondents lived in or around the capital of Hungary, i.e., the majority did so. 177 respondents claimed to have an "average" income, while the second most common income level was "good". Only 16 respondents claimed to have a "below average" or "poor" income. The mean age of the children was 4.51 years. Apart from the 35-item Child Eating Behavior Questionnaire, the survey included numerous questions regarding the children's media consumption habits as well as any form of possible allergies or illnesses the children might have regarding their daily food consumption. The most common food allergy was lactose intolerance, which affected $6.8 \%$ of the children in the sample. The average television viewing time for the children was "between 1-2 hours" daily. The demographic characteristics of the participants are summarized in Table 1.

Selected Demographic Characteristics of the Sample Participating in the Survey

\begin{tabular}{|c|c|c|c|}
\hline Characteristics & & Frequency & Percentage $(\mathrm{N}=\mathbf{3 6 5})$ \\
\hline \multirow[t]{3}{*}{ Gender } & Boy & 200 & 54.8 \\
\hline & Girl & 165 & $45 \cdot 2$ \\
\hline & Total & 365 & 100.0 \\
\hline \multirow[t]{6}{*}{ Age } & 3 & 119 & 32.6 \\
\hline & 4 & 74 & 20.3 \\
\hline & 5 & 77 & 21.1 \\
\hline & 6 & 58 & $15 \cdot 9$ \\
\hline & 7 & 37 & 10.1 \\
\hline & Total & 365 & 100.0 \\
\hline \multirow[t]{6}{*}{ Family income } & Poor & 2 & 0.5 \\
\hline & Below average & 14 & 3.8 \\
\hline & Average & 177 & 48.5 \\
\hline & Good & 116 & 31.8 \\
\hline & Very good & 33 & 9.6 \\
\hline & Total & 342 & 100.0 \\
\hline \multirow[t]{8}{*}{ Region } & Central Hungary (Budapest) & 190 & 52.1 \\
\hline & Northern Hungary & 29 & 7.9 \\
\hline & Northern Great Plain & 59 & 16.2 \\
\hline & Western Transdanubia & 13 & 3.6 \\
\hline & Southern Great Plain & 23 & 6.3 \\
\hline & Southern Transdanubia & 9 & 2.5 \\
\hline & Central Transdanubia & 19 & 5.2 \\
\hline & Total & 342 & 100.0 \\
\hline
\end{tabular}

Source: Own compilation 


\section{RESULTS}

The results were explored via multidimensional scaling, and a Euclidean two-dimensional distance model was created using SPSS. Figure 1 provides a graphical depiction of the relationships between the items by placing them in two-dimensional space. A dimension reduction algorithm calculates locations of the items in space according to the "similarity" or "dissimilarity" of responses among the items. If two items are placed close together, this indicates that parents who reported a high score on one item were likely to report a high score on the other. The distance model reveals a total of three eating behaviour clusters. The three clusters produced are overeating, fussy eater and enjoys nourishment.

\section{Perceptual Map of the Euclidean Distance Model Showing the Relationship Between Eating Behaviors and Genders}

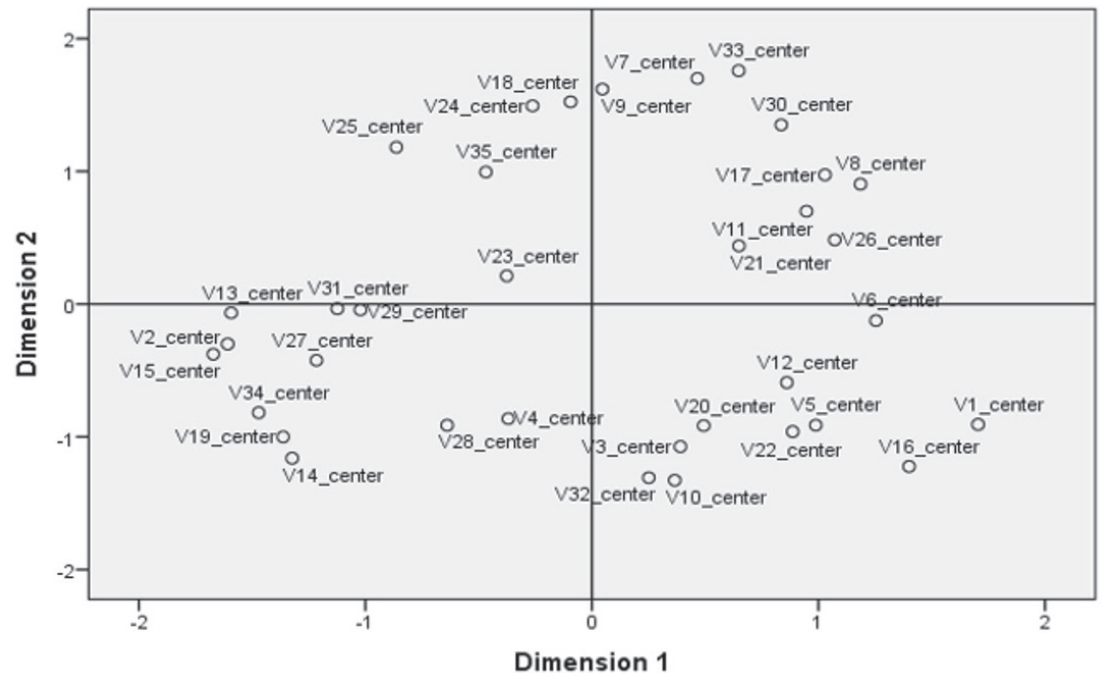

Source: Own compilation using SPSS

Notes: Derived Stimulus Configuration Individual differences (weighted) Euclidean distance model

The results of the analysis concluded that there are substantial differences in the genders regarding eating behavior; however it remains to be clarified which of the items are specifically true for a certain gender at this point. A common approach to interpreting the results is simply to observe the clusters on the perceptual map. However, to get a clearer picture, the exact weights of the variables were analyzed separately.

Examination of the weights reveal that four items from the CEBQ can be associated with boys (9, 18, 32 and 24) and six with the girls $(31,29,13,6,23$ and 2). The distances of all items selected for the respective genders were between 0 and 0.3 from the dimension axes. The exact results are summarized in Table 2. Boys are fussier eaters, they have a slow eating pace and have tendency towards emotional undereating. At the same time, they are interested in tasting new foods. On the other hand, girls tend to engage in emotional overeating and drink more often. 
Differences in Eating Behavior Between Girls and Boys

\begin{tabular}{|c|c|}
\hline Boys & Girls \\
\hline v18: My child takes more than 30 minutes to finish a meal & $\begin{array}{l}\text { v31: If given the chance, my child would always be having } \\
\text { a drink }\end{array}$ \\
\hline v9: My child eats less when angry & $\begin{array}{l}\text { v29: If given the chance, my child would drink conti- } \\
\text { nuously throughout the day }\end{array}$ \\
\hline $\begin{array}{l}\text { v32: My child is interested in tasting food s/he hasn't } \\
\text { tasted before }\end{array}$ & v13: My child eats more when annoyed \\
\hline \multirow[t]{3}{*}{ v24: My child is difficult to please with meals } & v6: My child is always asking for a drink \\
\hline & v23: My child eats more when she is happy \\
\hline & v2: My child eats more when worried \\
\hline
\end{tabular}

Source: Own compilation

\section{Conclusions and SUGGESTIONS}

Interestingly the results are rather diverse, i.e., many of the results obtained can be validated with past findings, not all findings are in line with past research in this field, and some of the results have not really been discussed to this point. As mentioned, fussy eating amongst children is a highly a debated subject and past research results in this particular field are rather inconsistent.

Even one of the present findings regarding the boys' sample is slightly contradictory, as one of the results state that boys are interested in tasting food that they have not tasted before, while they are also difficult to please. However, together with the other two findings, namely, that they are slow eaters and eat less when experiencing negative emotions, this result underlines that boys have a higher tendency towards fussy eating; this was also underlined by past research (COOKE and WARDLE, 2005; MASCOLA et al., 2010). At the same time, according to the present results, they are open to tasting new foods; nevertheless, this does not mean that they like the new foods they taste. This specific finding is definitely worth investigating further, perhaps even as part of a qualitative study. Another possible explanation for the current findings can be linked to the study of MASCOLA et al. (2010), who found that parents of fussy boys, were more likely to offer a reward to encourage eating, giving these children an incentive to try new foods. The same study also found that boys identified as fussy eaters were more likely to have tantrums, which could explain why boys tend to eat less when angry according to the current findings. Finally as WARDLE et al. (2001a) and COOKE and WARDLE (2005) pointed out, younger boys dislike more foods than girls, which explains why they are so hard to please at mealtime. The finding regarding the slower eating pace of boys is new and cannot be neither confirmed nor refuted, and this slower pace might well be linked to boy's fussiness.

The findings for the girls are divided into two groups, with the results being linked to either to fluid consumption or emotional overeating. Past research has not only found that girls are more emotional than boys (HAYCRAFT et al., 2011) but it has also linked emotional eating with girls (ESCOBAR et al., 2014; SILVEIRA et al., 2012). The new insight gained from this study is that girls tend towards emotional overeating when they are annoyed or worried, but can exhibit the behavior even when they are happy. Furthermore, the current study found that girls ask for drinks more than boys and prefer drinking throughout the day. However, it should to be noted that the findings do not reflect on the total fluid consumption of the children, only on how often they ask for drinks. Studies on this specific issue are highly scarce, as papers focus mainly on the eating, and not the drinking behavior of the children. Still, the current results are partially in line with the findings of GUELINCKX et al. (2015), who found that water and hot beverage intake is slightly higher for girls yet there are differences between countries. Unfortunately, 
no past papers focused on the frequency of fluid consumption in young children; however, three different survey items regarding drinking were true for girls, not boys, highlighting the relevance of the subject.

Evidently, the reasons behind certain gender differences regarding eating behaviors are vast and could extend back to the infant stage. A study found that, for example, breastfeeding and the introduction of complementary foods after 6 months of age reduced the odds of picky eating during early childhood (SHIM et al., 2011), while another study found a positive association between breastfeeding for less than 6 months and picky eating in 7-year-old girls (GALLOWAY et al., 2005). Furthermore, other factors can also influence eating behaviors, such as the presence of siblings. Findings have indicated the presence of older siblings may affect picky eating; boys who had older siblings were less likely to be picky eaters, whereas girls with older siblings had a higher risk of being picky eaters at the age of 5 years (JACOBI et al., 2003). Finally, parental feeding practices and perception are also known to influence eating behavior. Society holds diverse body ideals for men and women. Girls are usually encouraged to look thin, whereas boys are encouraged to be muscular and robust. These expectations have existed for over decades; thus, they are partially embedded in parents, who then raise their children accordingly, affecting their eating habits (HOLM-DENOMA et al., 2005). The hypothesis of the present study can be accepted, namely that gender differences exist in regards to emotional eating as well as fussy eating. Furthermore, there are differences in the beverage consumption behaviors of the genders, too, an aspect not covered by the hypothesis.

To conclude, the findings above can be extremely useful in a wide range of industries. Today, capturing preschool children's brand loyalties has become just as important as capturing adults', as this can be a significant market advantage in the long run. Children's brand loyalties start evolving at an extremely young age, which later on has an effect on their entire lives. The information above can therefore be of great use to marketers in the food and beverage industry, as they will be able to target children according to their genders more specifically. Healthcare professionals can use the findings to increase the awareness of certain techniques parents can use to improve their children's food consumption habits and reduce their energy intake, when necessary. For example, DECOSTA et al. (2017) looked into strategies that changed the eating behaviors of children and found that hands-on approaches, such as gardening and cooking programs, may encourage greater vegetable consumption and may have a larger effect compared to nutritional education. Providing children with free, accessible fruits and vegetables has been experimentally shown to positively affect longterm eating behavior. It is essential to educate the parents of the children, as well, primarily by not only showing them the possible negative consequences of certain eating habits, but also by coaching them on what a healthy diet should consist of and what healthy eating behaviors are ideal. Furthermore, a study by VAN STRIEN et al. (2013) has shown that emotional eating moderates the relationship between mood and food intake, especially in the case of sweet foods. It is the responsibility of the media, in conjunction with public health policymakers, to take specific measures so that the content of food advertisements during children's TV programs promotes healthy food choices. It should also be noted, that future nutritional policies could be more effective if they aim to install a positive association between healthy foods and deriving pleasure from eating in children. It has been assumed that providing nutritional information, i.e., pointing out which types of foods are "good" or "bad" for health, would drive healthier food choices; however, according to MARTY et al. (2018), such strategies have a limited impact on healthy choices and can even be counterproductive, leading children to avoid healthy foods.

To deepen the understanding of the differences in eating behaviors of preschool children, it would be vital to conduct this study internationally as well, as the findings of GUELINCKX et al. (2015) suggested that there are numerous differences between countries when it comes to eating and drinking behaviors in children. Furthermore, the study 
could be combined with a study on the media consumption of these children, as differences in eating habits as well as obesity have all been associated with the media consumption of children in past literature. Additionally, the link between different parenting styles and eating behaviors could also be analyzed further by extending this study; there are some studies that have been done, but there is still room for further analysis in this area, as is true for the presence of siblings, as well. In addition, any possible links between food allergies and other intolerances and eating behavior could be analyzed. Finally, the current study's results could further be validated with numerous types of qualitative studies, such as observations and in-depth interviews with parents as well as children.

Unfortunately, this paper is also not without limitations. The sample is rather unbalanced regarding the regional heritage of the respondents. More than half of the results (55.6\%) are from the central region of Hungary (including the capital, Budapest), whilst, up to this point, eating habits have hardly been studied in smaller suburbs and villages. Thus, more proportional sampling could have resulted in interesting insights in this specific field. Furthermore, the study of HOLM-DENOMA et al. (2005) on parental feeding habits regarding 3-year-old children showed, that parents often reported on the eating habits of children differently, depending on the gender of the child, thus the answers received by the respective parents may be biased depending on their child's gender. Also the questions asked in the Children's Eating Behavior Questionnaire could be clarified further, for example eating fussiness is a term with no single widely accepted definition (TAYLOR et al., 2015); therefore, different parents could perceive the eating fussiness of their child in completely different ways.

\section{SUMMARY}

The findings indicated that differences between the eating behaviors of genders do exist. According to the results above, boys willingness to try new foods differs that of girls', as well as their pace of food intake, they also tend to show emotional undereating. At the same time, girls tend to emotional overeating; furthermore, their desire to consume fluids differs from the opposite gender. Regrettably, some of these eating behaviors can have serious long-term effects on the children. For instance, fussy eating, especially a decreased willingness to try new foods, can often result in a lack of food variety intake. Amongst others, vegetable and fruit intake are lower within picky eaters (HORODYNSKI et al., 2010) and thus a lower consumption of vitamins (CARDONA et al., 2015), while they often consume a higher amount of snacks and sweets that are mainly higher calories (THARNER et al., 2015). All of these can lead to eating disorders (MARCHI and COHEN, 1990) as well as obesity (DEMIR and BEKTAS, 2017; FINISTRELLA et al., 2012). 


\section{REFERENCES}

Ainuki, T. - Rie, A.: Association Between Children's Appetite Patterns and Maternal Feeding Practices. Food and Nutrition Sciences. 2011. 2 (3) 228. DOI: https:// doi.org/10.4236/fns.2011.23032

Archer, L. A. - Rosenbaum, P. L. Streiner, D. L.: The Children's Eating Behavior Inventory: Reliability and Validity Results. Journal of Pediatric Psychology. 1991. 16 (5) 629-642. DOI: https://doi.org/10.1093/jpepsy/16.5.629

Ashcroft, J. - Semmler, C. - Carnell, S. - Van Jaarsveld, C. H. M. - Wardle, J.: Continuity and Stability of Eating Behavior Traits in Children. European Journal of Clinical Nutrition. 2007. 62 (8) 985-990. DOI: https://doi.org/10.1038/ sj.ejcn.1602855

Babbitt, R. L. - Edlen-Nezien, L. Manikam, R. - Summers, J. Murphy, M.: Assessment of Eating and Weight-Related Problems in Children and Special Populations: Measures, Theory, and Research. Handbook of Assessment Methods for Eating Behaviors and WeightRelated Problems. Edited by: Allison, D. B. Thousand Oaks, California, Sage Publications, 1995.

Barta, B. - Szúcs, R. S.: Reklámozás, szlogen és szuperhősök - A gyermekek meggyőzésének eszközei. Táplálkozásmarketing. 2015. 2 (2) 4757. DOI: https://doi.org/10.20494/ $T M / 2 / 2 / 4$

Bellissimo, N. - Pencharz, P. B. Thomas, S. G. - Anderson, G. H.: Effect of Television Viewing at Mealtime on Food Intake After a Glucose Preload in Boys. Pediatric research. 2007. 61 (6) 745-749. DOI: https://doi.org/oo313998/07/6106-0745

Blissett, J. - Haycraft, E. - Farrow, C.: Inducing Preschool Children's Emotional Eating: Relations with Parental Feeding Practices. The American Journal of Clinical Nutrition. 2010. 92 (2) 359-365. DOI: https://doi.org/10.3945/ajcn.2010.29375
Cardona Cano, S. - Tiemeier, H. - Van Hoeken, D. - Tharner, A. - Jaddoe, V. W. - Hofman, A. - Hoek, H. W.: Trajectories of Picky Eating During Childhood: A General Population Study. International Journal of Eating Disorders. 2015. 48 (6) 570-579. DOI: https://doi. org/10.1002/eat.22384

Carnell, S. - Wardle, J.: Measuring Behavioral Susceptibility to Obesity: Validation of the Child Eating Behavior Questionnaire. Appetite. 2007. 48 (1) 104-113. DOI: https://doi.org/10.1016/j. appet.2006.07.075

Cooke, L. J. - Wardle, J.: Age and Gender Differences in Children's Food Preferences. British Journal of Nutrition. 2005. 93 (5) 741-746. DOI: https://doi.org/10.1079/ BJN20051389

DeCosta, P. - Møller, P. - Frøst, M. B. - Olsen, A.: Changing Children's Eating Behavior - A Review of Experimental Research. Appetite. 2017. 113 327357. DOI: https://doi.org/10.1016/j. appet.2017.03.004

Del Toro, W. - Greenberg, B. S.: Television Commercials and Food Orientations Among Teenagers in Puerto Rico. Hispanic Journal of Behavioral Sciences. 1989. 11 (2) 168-177. DOI: https://doi. org/10.1177/07399863890112006

Demir, D. - Bektas, M.: The Effect of Childrens' Eating Behaviors and Parental Feeding Style on Childhood Obesity. Eating behaviors. 2017. 26 137-142. DOI: https:// doi.org/10.1016/j.eatbeh.2017.03.004

Dörnyei, K. - Gyulavári, T. - HofmeisterTóth, Á. - Jenes, B. - Jentetics, K. Neumann Bódi, E. - Neulinger, Á. - Simon, J. - Zsótér, B.: Marketing az egészségtudatosságért - a marketing pozitív szerepe az egészség-tudatosságtól a termékválasztásig. Tomcsányi Pál akadémikus 90 éves: Az életminőség anyagi és szellemi igényeinek kielégítése fogyasztási marketing szemlélettel: Felolvasó ülés és tanulmánykötet. MTA Agrár-közgazdasági Bizottság Agrármarketing Albizottság, Budapest, 2014. 65-91. 
Edlund, B. - Halvarsson, K. - Sjödén, P. O.: Eating Behaviors, and Attitudes to Eating, Dieting, and Body Image in 7-year-old Swedish Girls. European Eating Disorders Review. 1996. 4 (1) 40-53. DOI: https://doi.org/10.1002/ (SICI)1099-0968(199603)4:1<40::AIDERV1OO>3.0.CO;2-6

Escobar, R. S. - O'Donnell, K. A. Colalillo, S. - Pawlby, S. - Steiner, M. - Meaney, M. J. - MAVAN Study Team.: Better Quality of Mother-Child Interaction at 4 Years of Age Decreases Emotional Overeating in IUGR Girls. Appetite. 2014. 81 337-342. DOI: https:// doi.org/10.1016/j.appet.2014.06.107

Finistrella, V. - Manco, M. - Ferrara, A. - Rustico, C. - Presaghi, F. Morino, G.: Cross-Sectional Exploration of Maternal Reports of Food Neophobia and Pickiness in Preschooler-Mother Dyads. Journal of the American College of Nutrition. 2012. 31 152-159. DOI: https:// doi.org/10.1080/07315724.2012.107200 22

Galloway, A. T. - Fiorito, L. - Lee, Y. Birch, L. L.: Parental Pressure, Dietary Patterns, and Weight Status Among Girls Who Are "Picky Eaters". Journal of the American Dietetic Association. 2005. 105 541-548. DOI: https://doi.org/10.1016/j. jada.2005.01.029

Guelinckx, I. - Iglesia, I. - Bottin, J. H. De Miguel-Etayo, P. - González-Gil, E. M. - Salas-Salvadó, J. - Abdollahi, M.: Intake of Water and Beverages of Children and Adolescents in 13 Countries. European Journal of Nutrition. 2015. 54 (2) 69-79. DOI: https://doi.org/10.1007/ soo394-015-0955-5

Harris, H. - Mallan, K. M. - Nambiar, S. - Daniels, L. A.: The Relationship Between Controlling Feeding Practices and Boys' and Girls' Eating in the Absence of Hunger. Eating behaviors. 2014. 15 (4) 519-522. DOI: https://doi.org/10.1016/j. eatbeh.2014.07.003
Haycraft, E. - Farrow, C. - Meyer, C. Powell, F. - Blissett, J.: Relationships Between Temperament and Eating Behaviors in Young Children. Appetite. 2011. 56 (3) 689-692. DOI: https://doi. org/10.1016/j.appet.2011.02.005

Hendy, H. M. - Raudenbush, B.: Effectiveness of teacher Modeling to Encourage Food Acceptance in Preschool Children. Appetite. 2000. 34 (1) 6176. DOI: https://doi.org/10.10o6/ appe.1999.0286

Hofmeister-Tóth, Á.: Fogyasztói értékek, trendek és magatartás: Korreferátum Törőcsik Mária: A fogyasztói magatartás új tendenciái címú tanulmányához. Vezetéstudomány. 2016. 47 (4) 26-29. 21.

Holm-Denoma, J. M. - Lewinsohn, P. M. - Gau, J. M. - Joiner, T. E. Striegel-Moore, R. - Otamendi, A.: Parents' Reports of the Body Shape and Feeding Habits of 36-Month-Old Children: An Investigation of Gender Differences. International Journal of Eating Disorders. 2005. 38 (3) 228-235. DOI: https://doi. org/10.1002/eat.2018o

Horodynski, M. A. - Stommel, M. - Brophy-Herb, H. - Xie, Y. Weatherspoon, L.: Low-Income African American and Non-Hispanic White Mothers' Self-Efficacy, "Picky Eater" Perception, and Toddler Fruit And Vegetable Consumption. Public Health Nursing. 2010. 27 408-417. DOI: https:// doi.org/10.1111/j.1525-1446.2010.00873.x Jacobi, C. - Agras, W. S. - Bryson, S. - Hammer, L. D.: Behavioral validation, precursors, and concomitants of picky eating in childhood. Journal of the American Academy of Child and Adolescent Psychiatry. 2003. 42 (1) 76-84. DOI: https://doi.org/10.1097/oooo4583200301000-00013 
Keller, K. L. - Kuilema, L. G. - Lee, N. Yoon, J. - Mascaro, B. - Combes, A. L. - Halford, J. C. G.: The Impact of Food Branding on Children's Eating Behavior and Obesity. Physiology and Behavior. 2012. 106 (3) 379-386. DOI: https://doi. org/10.1016/j.physbeh.2012.03.011

Keller, V. - Dernóczy-Polyák, A. Ercsey, I.: A háromfaktoros evési kérdőív alkalmazási lehetőségei a marketingkutatásban - Nem és generációk közötti eltérések. Táplálkozásmarketing. 2016. 3 (1) 1-20. DOI: https://doi. org/10.20494/TM/3/1/1

Le Bigot Macaux, A.: Eat to Live or Live to Eat? Do Parents and Children Agree? Public Health Nutrition. 2001. 4 141146. DOI: https://doi.org/10.1079/ PHN200O1O9

Lerner, G.: The Creation of Patriarchy. 1986. New York: Oxford University Press.

Lytle, L. A. - Seifert, S. - Greenstein, J. - McGovern, P.: How Do Children's Eating Patterns and Food Choices Change Over Time? Results from a Cohort Study. American Journal Health Promot. 2000. 14 222-228. DOI: https://doi. org/10.4278/o890-1171-14.4.222

Marchi, M. - Cohen, P.: Early Childhood Eating Behaviors and Adolescent Eating Disorders. Journal of the American Academy of Child \& Adolescent Psychiatry. 1990. 29 (1) 112-117. DOI: https://doi. org/10.1097/00004583-199001000ooo17

Marty, L. - Chambaron, S. - Nicklaus, S. - Monnery-Patris, S.: Learned pleasure from eating: An opportunity to promote healthy eating in children? Appetite. 2018. 120 265-274. DOI: https://doi. org/10.1016/j.appet.2017.09.006

Mascola, A. J. - Bryson, S. W. - Agras, W. S.: Picky Eating During Childhood: A Longitudinal Study to Age 11years. Eating behaviors. 2010. 11 (4) 253257. DOI: https://doi.org/10.1016/j. eatbeh.2010.05.006

McNeal, J. U.: Kids as Customers: A Handbook of Marketing to Children. 1992. Lexington Books.
Moroshko, I. - Brennan, L.: Maternal Controlling Feeding Behaviors and Child Eating in Preschool-Aged Children. Nutrition \& Dietetics. 2013. 70 (1) 49-53. DOI: $\quad$ https://doi.org/10.1111/j.1747oo80.2012.01631.x

Neulinger, Á.: Born to buy? The Influence of Consumer Kids on Family Consumption. 2. Kids and Retailing Colloquium: Future trends. 2015. Budapest, 18-19 June.

Neulinger, Á. - Simon, J.: Food Consumption Patterns and Healthy Eating Across the Household Life Cycle In Hungary. International Journal of Consumer Studies. 2011. 35 (5) 538-544. DOI: $\quad$ https://doi.org/10.1111/j.147O6431.2011.01015.x

Perez-Rodrigo, C. - Ribas, L. - SerraMajem, L. - Aranceta, J.: Food Preferences of Spanish Children and Young People: The Enkid Study. European Journal of Clinical Nutrition. 2003. 57 Suppl. 1. 45-48. DOI: https://doi. org/10.1038/sj.ejcn.1601814

Powers, S. W. - Chamberlin, L. A. Van Schaick, K. B. - Sherman, S. N. - Whitaker, R. C.: Maternal Feeding Strategies, Child Eating Behaviors, and Child Bmi in Low-Income AfricanAmerican Preschoolers. Obesity. 2006. 14 (11) 2026-2033. DOI: https://doi. org/10.1038/oby.2006.237

Rodgers, R. F. - Paxton, S. J. - Massey, R. - Campbell, K. J. - Wertheim, E. H. - Skouteris, H. - Gibbons, K.: Maternal Feeding Practices Predict Weight Gain and Obesogenic Eating Behaviors in Young Children: A Prospective Study. International Journal of Behavioral Nutrition and Physical Activity. 2013. 10 (1) 24. DOI: https://doi.org/10.1186/14795868-1O-24

Romero, N. D. - Epstein, L. H. - Salvy, S. J.: Peer modeling influences girls' snack intake. Journal of the American Dietetic Association. 2009. 109 (1) 133136. DOI: https://doi.org/10.1016/j. jada.2008.10.005 
Rydell, A. M. - Dahl, M. - Sundelin, C.: Characteristics of School Children Who Are Choosy Eaters. The Journal of Genetic Psychology. 1995. 156 (2) 217-229. DOI: https://doi.org/10.1080/oo221325.1995. 9914818

Salvy, S. J. - Romero, N. - Paluch, R. - Epstein, L. H.: Peer Influence on Preadolescent Girls' Snack Intake: Effects of Weight Status. Appetite. 2007. 49 (1) 177-182. DOI: https://doi.org/10.1016/j. appet.2007.01.011

Sasson, A. - Lewin, C. - Roth, D.: Dieting Behavior and Eating Attitudes in Israeli Children. International Journal of Eating Disorders. 1995. 17 (1) 67-72. DOI: $\quad$ https://doi.org/10.1002/1098$108 X(199501) 17: 1<67:: A I D-$ EAT2260170109>3.O.CO;2-B

Shim, J. E. - Kim, J. - Mathai, R. A. - STRONG Kids Research Team: Associations of Infant Feeding Practices and Picky Eating Behaviors of Preschool Children. Journal of the American Dietetic Association. 2011. 111 (9) 13631368. DOI: https://doi.org/10.1016/j. jada.2011.06.410

Silveira, P. P. - Agranonik, M. - Faras, H. - Portella, A. K. - Meaney, M. J. - Levitan R. D.: Preliminary evidence for an impulsivity-based thrifty eating phenotype. Pediatric Research. 2012. 71 293-298. DOI: https://doi.org/10.1038/ pr.2011.39

Svensson, V. - Lundborg, L. - Cao, Y. Nowicka, P. - Marcus, C. - Sobko, T.: Obesity Related Eating Behavior Patterns in Swedish Preschool Children And Association With Age, Gender, Relative Weight And Parental Weight-Factorial Validation of the Children's Eating Behavior Questionnaire. International Journal of Behavioral Nutrition and Physical Activity. 2011. 8 (1) 134. DOI: https://doi.org/10.1186/1479-5868-8-134
Taylor, C. M. - Wernimont, S. M. Northstone, K. - Emmett, P. M.: Picky/Fussy Eating in Children: Review of Definitions, Assessment, Prevalence and Dietary Intakes. Appetite. 2015. 95 349-359. DOI: https://doi.org/10.1016/j. appet.2015.07.026

Tharner, A. - Jansen, P. W. - Kiefte-de Jong, J. C. - Moll, H. A. - Hofman, A. - Jaddoe V. W. V.: Bidirectional Associations Between Fussy Eating And Functional Constipation in Preschool Children. Journal of Pediatrics. 2015. 166 91-96. DOI: https://doi.org/10.1016/j. jpeds.2014.09.028

Tremblay, L. - Rinaldi, C. M.: The Prediction of Preschool Children's Weight from Family Environment Factors: GenderLinked Differences. Eating Behaviors. 2010. 11 (4) 266-275. DOI: https://doi. org/10.1016/j.eatbeh.2010.07.005

Valkenburg, P. M. - Cantor, J.: The Development of a Child Into a Consumer. Journal of Applied Developmental Psychology. 2001. 22 (1) 61-72. DOI: https://doi.org/10.1016/So1933973(oo)0oo66-6

vanStrien, T. - Cebolla, A. - Etchemendy, E. - Gutierrez-Maldonado, J. Ferrer-Garcia, M. - Botella, C. Baños, R.: Emotional Eating and Food Intake After Sadness and Joy. Appetite. 2013. 66 20-25. DOI: https://doi. org/10.1016/j.appet.2013.02.016

Viana, V. - Sinde, S. - Saxton, J. C.: Children's Eating Behavior Questionnaire: Associations with BMI in Portuguese Children. British Journal of Nutrition. 2008. 100 (2) 445-450. DOI: https://doi. org/10.1017/Sooo7114508894391

Wardle, J. - Guthrie, C. A. - Sanderson, S. - Rapoport, L.: Development of the Children's Eating Behavior Questionnaire. Journal of Child Psychology and Psychiatry. 2001a. 42 (7) 963-970. DOI: https://doi. org/10.1017/Soo21963001007727 
Wardle, J. - Sanderson, S. - Gibson, E. L. - Rapoport, L.: Factor-Analytic Structure of Food Preferences in FourYear-Old Children in the UK. Appetite. 2001b. 37 217-223. DOI: https://doi. org/10.1006/appe.2001.0423

Wilson, J. F.: Lunch Eating Behavior Of Preschool Children: Effects of Age, Gender, and Type of Beverage Served. Physiology \& Behavior. 2000. 70 (1) 2733. DOI: https://doi.org/10.1016/Soo319384(oo)oo230-4
Yavas, U. - Abdul-Gader, A.: Impact of TV Commercials on Saudi Children's Purchase Behavior. Marketing Intelligence \& Planning. 1993.11(2) 37-43. DOI: https:// doi.org/10.1108/02634509310027837

\section{JEGYZETEK $\rightsquigarrow$ NOTES}

